\title{
Rethinking democracy in twenty-first century Europe: The role of ancient democracy
}

\author{
B. N. Koljević Griffith \\ University of Belgrade, \\ 36, ul. Svetozara Marcovića, Belgrade, 11000, Republic of Serbia
}

For citation: Koljević Griffith B. N. Rethinking democracy in twenty-first century Europe: The role of ancient democracy. Vestnik of Saint Petersburg University. Philosophy and Conflict Studies, 2020, vol. 36, issue 4, pp. 700-708. https://doi.org/10.21638/spbu17.2020.408

In this article, the author discusses how the crisis of the contemporary European Union appears not merely as a crisis of the so-called "democratic deficit", the way in which Habermas has most notably articulated this argument, but rather as a structural and original crisis of political subjectivity and democracy per se. In other words, the crisis of the EU is systemic and refers to the concept of the political - especially in the context of twenty-first century Europe. In this framework, the differentiation between the concepts of Europe and the EU particularly discloses the neoliberal and postmodern character of the latter, i. e., at the same time the struggle for self-governance and autonomy of the former. Moreover, it is argued how it is precisely the return to ancient democracy that reveals the path for rethinking true democracy of contemporary Europe. This is especially emphasized in reference to both practices and the concept of the polis. In conclusion, it is claimed that new politics of emancipation, which first and foremost go back to the meaning of isonomia and isegoria and as such presents the project of autonomy, presents a reappearance of ancient democracy in contemporary times. Finally, this project is articulated as one of politics of time and likewise politics of locality.

Keywords: European Union, Europe, $21^{\text {st }}$ century, true democracy, political subjectivity, polis.

\section{The contemporary crisis of the European Union: The issues of political subjectivity and democracy in the $21^{\text {st }}$ century}

In the last decade, numerous and different political philosophers have raised the critical question of the theoretical and practical outlook of the contemporary European Union, emphasizing its undemocratic and domineering character. In this vein, Etienne Balibar's well known statement is exemplary: "Europe is a dead political project because some countries are dominant, and others are dominated" [1, p.26]. In similar fashion, Ulrich Beck published his German Europe in 2013 asking the following question: "What kind of a world is it, in which one country gets to decide the destiny of another and in which something like this is accepted as a normal state of things?" [2, p.26]. Or, indeed, one can remember Habermas's claim that the EU has entered a post-democratic era due to the monopolization of the European project by self-proclaimed elites, who produced bureaucratization and democracy as a façade, as well as Habermas's other critiques of the EU project, most notably elaborated upon in The Crisis of the European Union [3, p. 12-53]. Furthermore, we can recall either Alain Badiou or Jacques Rancière's critiques of the never

(c) Санкт-Петербургский государственный университет, 2020 
adopted European Constitution, namely the reaction of the French government to the referendum whose position was that the people did not understood [4, p. 37-39] ${ }^{1}$.

What all these insights from quite different philosophers have in common is the exposure of the fact that the European Union has failed in a grandiose manner and its current political, social and economic crisis - such as the migrant crisis, the Brexit crisis, the crisis of the euro or the crisis that developed with COVID 19 - are merely a reflection of a more profound, basically original, crisis that is one of political subjectivity and democracy. Moreover, all these different examples of crises of the EU are themselves an illustration of biopolitics as neoliberalism in the twenty-first century [5, p. 77-92], which appears as governing over entire populations. In the center of these processes of control is the concept of bare life operationalized in the way that the individual, due to fearing life and security, abandons all normative frameworks.

These are the key reasons why it is, first and foremost, worthwhile to remember the conceptual difference between Europe and the European Union, which is namely that the $\mathrm{EU}$ is a specific political and economic project while the concept of Europe is philosophically broader not only in terms of its topos, but also in the horizon of historical time. This all marks the qualitative distinctiveness of Europe.

To speak, therefore, about contemporary Europe and democracy means something other than to, for example, take notice of the EU's structural democratic deficit which has been a popular subject of debate in recent years but nonetheless, as such, persists within the analysis and practices of the status quo. Moreover, this "something other" is now two-fold in of itself. First, it signifies the outlined distinction between the concepts of the European Union and Europe, and second, it refers to the concept of democracy per se, specifically to the fact that democracy actually goes beyond liberal-democratic procedures. Therefore, neither the Habermasian nor Rawlsian approach can capture the structural gap between EU forms and European realities. Likewise, in this sense, Rancière, for example, argues how the cause of the post-democratic condition in contemporary times is precisely the dominance of the procedural theory of democracy, such as Dahl's, with the emphasis that liberal democracy is an unnatural bond between democracy and the individual race for profit. In Hatred of Democracy, Rancière, moreover, turns to Plato's critique of democracy in order to underline all its similarities with the contemporary condition, especially the egoistic individual and the concept of false equality in a time of mass consumerism. Simultaneously, Rancière reminds us of postmodern sociologists who were in favor of such democracy as consumerism [6, p. 22-36].

All this is to say the structural problem of the European Union is the fact that, both in theory and in its practices, it has been constructed and realized as a neoliberal project par excellence. More precisely it is a mixture of a neoliberal and postmodern project, keeping in mind here Robert Cooper's observation how the EU is equally "the most developed example of the postmodern system" [7, p.56].

The European Union's neoliberal character in the political, economic and social senses has, first and foremost, been the result of the consensus of EU crypto elites, most

${ }^{1}$ More accurately - as discussed in Chronicles Of Consensual Times - taking up the example of the French referendum on the EU constitution Rancière addresses the fact that both the so-called "conservative government" and "socialist opposition" called for a "yes" vote. The stated explanation that "the people have not understood" for Rancière is the example of the medicalization of thought with consequences for both theory and practice. 
associated with Giddens's "third way" theory and, on the political level, with the BlairSchroederian empty formula "beyond left and right." The formula was conceived as the utmost of paradoxical alliances between social-democracy and economic neoliberalism. When this neoliberal pact became the basis of the so-called "social-democratic" political parties in Europe, an entire spectrum of what Nancy Fraser calls "neoliberalism light" [8, p.11] entered the scene and one of the outcomes of these processes has been the loss of democracy.

In a condition of a systemic political simulacrum, a paradigmatic example of what Baudrillard names as simulation, the outcome had to be a mimesis of politics. Furthermore, in the hyperproduction of the other of the same of the system, the crisis of the European Union appeared as the crisis of the political as such because it created a rupture between the polis and the demos as the governing elites became counterposed to the people. Therefore, the first decades of the twenty-first century demonstrated practically the mutual exclusion between the two, where "the city", the topos of the political, emerged as dislocated from the body of the citizens qua citizens. The polis, the presupposed place of self-governance and autonomy, in this case arose as hostile to the people and, in consequence, the demos itself appeared as hostile to it. Certainly, we have in mind here not only the physical space of the ancient agora within the polis, but the entire spectrum of the public space as the space in and through which the public is permanently created.

In other words, at issue is the breakdown of what was imagined to be a contemporary synoecism, a gathering which was, just as in ancient Greece, supposed to mark a specific political unification. A legitimate question to be put forth here is the following: if the EU cosmopolis now resembles more of a necropolis, a city of the dead, should it be left to rest in peace in the name of a new and different project of European integration or should attempts be made to restore the relation between the polis and the demos within the polis as is - and can this even, theoretically and practically, be done in the case of a project in systemic crisis?

If the rupture between the EU polis and its own demos is not simply political, economic and social, but a crisis that relates to subjectivity proper - in self-perception and self-comprehension as well as in its intersubjective apparatus - then it becomes clear that what is at stake is more than a structural democratic deficit, i. e., a specific surplus that goes to the heart of the matter. More accurately, what the argument about the 'democratic deficit' discloses is the profound contradiction of the concept of 'liberal democracy' as elaborated, for example, in the work of Chantal Mouffe.

Mouffe argues in detail how 'liberal democracy' has been the paradoxical attempt to reconcile two separate traditions, one of individual freedom and human rights (liberalism) and the tradition of concepts and practices of equality and popular sovereignty (democracy) [9, p.92-111]. As a result of the neoliberal pact, popular sovereignty has been excluded from public discourse, which in turn affected the democratic imaginary, as well as democratic institutions. However, this shows that what is at stake with democracy, and without accounting for the demos, is political subjectivity. In the case of the EU, this is the failure to embrace the multiplicity of its multiplicities, namely its different political and cultural identities. The attempt has been attempted to establish a oneness in place of different European identities which was mostly focused on technocratic efficiency, while decisive issues such as democracy, subjectivity and community were for the most part left aside. Even Jean Monnet, who thought that technocratic measures of economic integra- 
tion would ultimately lead to political unification, refused to ever provide a response as to what the European Union should become. From that point on, the matter of its purpose, i. e., its real telos, was left in the empty space of a vague oneness. Monnet's technocratic strategy never accounted for the contradictions of conflicting visions of European alliance and cooperation shaped through cultural-historical experiences of different demoi. In this sense, the limits of Monnet's method have been analyzed in detail, for example, in the work of Majone [10, p. 22-72].

It is precisely the concept of oneness which already presents a trace of totality in and of itself ${ }^{2}$ while, on the other hand, the concept of 'the many' is structurally linked to democracy as well as to political subjectivities in their democratic fashion. 'The many' in the European Union mainly appeared as the indicator of multiple divisions: between the South and North or between the East and West of Europe, between states as well as within states themselves. The current crisis with COVID 19, for example, illustrates a further deepening of these already present divisions and, moreover, refers to even greater fragmentation within the European Union. More accurately, not only is it the case that the EU failed to act as a unified subject during the peak of the health crisis - openly disclosing that the main political actors are states and not the union - but it has revealed differences as well as lack of cooperation between "the weaker" and "the stronger". Once again it has demonstrated the structural inequality between member-states in political, social and economic aspects, as well as the "disciplinary power" that accompanies the various divisions.

Along the same lines, the proposed concepts of a "two-speed" or "three-speed" Europe, or a Europe in "three circles" rearrange the problem towards structural differentiation where there is a political and legal distinctiveness, and, in doing so, further strengthen the already present hierarchical and class divisions which will become even more transparent in the post-pandemic world. Therefore, such an alternative is both de facto and de jure closer to the alternative of neocolonialism and a contemporary version of the Hegelian master-slave dialectic or indeed a Foucault's Panopticon than to any type of true democracy and subjectivity. It is neoliberalism as biopolitics precisely as a specific relation between knowledge and power which disturbs the political per se. In this way, the EU's neoliberalism, firstly, in its political and social aspects, has appeared as the real cause of the collapse of the contemporary European polis and its split from the demos, as the rupture between 'EU forms' and 'European realities' [11, p. 12ff.].

Moreover, this is precisely why a neoliberal polis is a contradictio in adjecto and why a neoliberal polis cannot exist. First, the concept of polis has as its ultimate references the creation of the body of the citizens as well as self-governance and autonomy. Second, as such, polis presupposes the highest relevance of the public space comprised of dialogue, debate and the participation of citizens. As a result, it refers to the community and togetherness, to the topos of the common as well as to the space of speech and decisions. Furthermore, in this way the concept of polis demonstrates how the political is structurally interrelated with collectivity, that is, with the body of politics as such. Besides, not only is a neoliberal polis therefore a paradox in of itself, but so is a neoliberal demos because demos refers to the collectivity of the people, to a community per se. In other words, in all the subtle aspects of its meaning, demos always refers to the concept of the common peo-

${ }^{2}$ One of the most far-reaching arguments in this sense has been provided in the work of Emanuel Levinas, esp. in Totality and Infinity (1961). 
ple, the ancient state, and is in this way diametrically opposed to the project of neoliberal crypto elites which has very little, almost nothing to do with democracy especially when compared to the first democracies created by the Greeks.

\section{The politics of emancipation and true democracy as egalitarianism}

There is something philosophically and politically relevant that, unintentionally, has been created by the neoliberal crypto elites. It is an empty space which Lefort articulates as the very condition for political praxis, and therefore as the topos of potentiality and creativity [12, p. 101-132]. In this case, the response to the empty place of the polis of the European Union is the return of the demos in its raw form. This equally corresponds to a certain type of hauntology, to the concept of the haunted and haunting other whose exclusion simultaneously represents the beginning of its rebirth. The return from the past in a ghostly manner, the situation of temporal and ontological disjunction [13, p. 49-77], and the persistence of the past in a manner of a retrofuturism and/or cultural memory here, first and foremost, refers to the demos of European states and its reappearance in multiple forms of current crisis.

Returning once more to ancient Greece, one can say this likewise resembles the beginning of the very beginning because it appears as the first moment in which polis and demos were historically and factually separated. In addition, this was the key split in that society. Demos signified "country people" and/or "country villages," while polis was the site of nobility and aristocracy and, moreover, the antagonism between the two bodies of "the country" and "the city" was extremely high. This was before demos and polis became identical in Athens, the process through which we then consider the birth of politics - as well as the birth of philosophy and the paradoxical relation between the two.

Now, if the entire matter was to be addressed from, for example, a Foucauldian perspective, the articulation would be as follows: the contemporary forms of governmentality, as they have been established in the last decades in Europe in the form of a special dispositif of management, failed to incorporate the demos not only in form but, more relevantly, in content, that is in the sense of a multiplicity of subjectivities which are self-constituted in the polis. Therefore, the act of refusal practiced by the demos is the act of re-appropriating one's own environment and is constituted in the right to say "no." Even further, if the politics of emancipation never comes from 'above', but always from the people themselves, and if, therefore, emancipation always presupposes self-emancipation, then it is precisely this movement that represents the possibility of the rebirth of both subjectivity and the polis.

Likewise, inasmuch as this refusal appears as a call for "equality", it emerges as an even greater potentiality because emancipation requires a démontage of all structures of inequality. On the threshold of the post-neoliberal era, with the birth of a new epoch for the twenty-first century, emancipation, first and foremost, demands the end of tutorial democracy and politics and, consequently, all practices of so-called "exporting democracy". In different ways, the dangers of "exporting democracy" have been elaborated on by, for instance, Hobsbawm [14, p. 122-146] and Barany and Moser [15, p. 22-46].

Finally, another way to address the matter is to perceive how, in Rancière's terms, true democracy cannot be crypto-pedagogical and therapeutic. It has to signify the end of the medicalization of thought which, as such, establishes hierarchical divisions. This is also why Mauricio Lazzarato writes how, for Rancière, in contrast, precisely democracy in 
ancient Greece demonstrated how the unique principle of politics is equality because both true politics and true democracy are based on egalitarianism and the will of the people $[16$, p. 121-126].

\section{The project of autonomy - isonomia and isegoria}

Democracy is the power of any and all to engage in public affairs at any time and always. As such, it is the second name of politics. In response to Plato, therefore, Rancière articulates that this is how demos is not ochlos, but rather, in the process of permanently building the political stage, becomes a subject. Furthermore, it is precisely the concept of autonomia which refers to political freedom, participation in public life as well as to decision-making which includes freedom of action in the public space. This is also the difference between citizens and barbarians because barbaro $i$ are exactly those who do not practice democracy, those who do not decide on their own politics, life and destiny. In this sense, Wendy Brown rightly emphasizes how demos and kratos are in opposition not only to aristocracy, oligarchy and tyranny, but to any situation of colonialism and occupation [17, p. 23]. Nadia Urbinati underlines how Athens was the first democracy because it attempted to break the continuity between wealth and political power.

Democracy meant that every citizen had an equal chance to participate in law-making and to speak about public affairs, for example each citizen had the equal right to address the political assemblies. Democracy meant isonomia and isegoria. Moreover, from Herodotus on, isonomia arises as the name for the rule of the people because that is the name of equality, while in Thucydides, like democracy, it is the alternative to both aristocracy and oligarchy. Arendt in On Revolution also argues that, at least from the time of Herodotus, isonomia in and of itself refers to freedom precisely in the context that it signifies the state of no-rule, a condition in which there is no distinction between the rulers and ruled. As the equality of those who form a body of peers, isonomia was the crux of the Greek polis and referred, therefore, to an entire conception of life in which isegoria is practiced as the participation of citizens in the creation of their own democracy. Furthermore, for Herodotus, isegoria was in fact the form of government in Athens. Fundamentally about equality, as such isegoria became the hallmark of Athenian democracy which was specific in comparison to other Greek city-states precisely because it included the poor. In addition to isonomia and isegoria, there were also the concept of 'one man, one vote' as isopsephos, as well as the concept of the equality of power as isokratia. In all these different ways of referring to equality, Athenian democracy proved in an exemplary way how political equality translates to freedom [18, p. 22-60].

Finally, in recalling all the impulses from the Greeks which are inspiring in contemporary political times, especially in terms of political creation besides the obvious with philosophers such as Arendt, one can think, for example, of the work of Cornelius Castoriadis. As a thinker of self-organization and anti-bureaucracy, Castoriadis emphasizes that the Greeks not only came forth and shone in glory - showing us who they are as unique actors in their distinctness, as Arendt has articulated it - but also made laws themselves through processes of collective deliberation, i. e., in the self-founding process of the becoming of the political.

Most notably, in the twin births of democracy and politics Castoriadis perceived a new phenomenon, a new grasp of the world which he calls 'the project of autonomy'. It is 
the Greeks who, for the first time in history, realized that a society's norms are not something imposed or derived from the outside but rather societies are created by themselves, that is, by us [19, p. 76-87]. In re-thinking political creation in our time - how a demos can re-create the polis so that a polis reappears qua polis - it is precisely the project of autonomy which can emerge as the proper name. If a demos is to decide on its own norms, it begins the process of emancipation first by re-appropriating its surroundings where movement is no longer an externality, an outside, but rather a subjectivity that actively builds the polis. Here it is also worthwhile to remember Debord's insights that, in ancient Greece, history and democracy entered the world at the same time and we can demonstrate that their disappearance was also simultaneous [20, p. 69]. Moreover, here we can equally recall the beginning of Hesiod's Theogony, which exemplifies how the beginning of the very beginning in ancient Greece, the beginning of philosophy, history, politics and the Western tradition en generale, has been, first and foremost, signified by the difference between truth and lies as well as the possibilities of both. In this sense, Hesiod writes "The Muses once taught Hesiod a beautiful song... we know how to say many lies like the truth and, whenever we wish, we know how to tell the truth" [21, p. 25].

It is this moment of truth coming into being that reveals the different dimensions of the European project of autonomy. Therefore, it becomes clearer how and why in the case of Europe in the twenty-first century the processes conceived and described in terms of new social contracts carry their proximity to the concept of self- becoming and selfdetermination. Moreover, this project of autonomy is one that can be realized through understanding both the politics of time and the politics of locality. The politics of time relates to the genealogy of political forms as well as to the perception of kairos, which is the proper time when conditions are fulfilled for the accomplishment of a crucial action. As such, the politics of time is practically inseparable from the politics of locality, from local topoi in and through which politics is created and through which political subjectivities take shape.

There is no politics without location and there is no democracy without politics proper. This locality is interrelated with the demos coming into being and is a presupposition for the development of polis. Moreover, if the politics of time re-invents the dimensions of past and future, in opposition to the neoliberal construct of the eternal present, the politics of topos enables the subjectification of praxis. Democracy can therefore be rethought as a local participative democracy that does away with the logic of ruling and ruled as well as with the logic of consumer society. Contrary to '(neo)liberal democracy', it dissolves the domineering structures and hierarchical divisions in and through its praxis which simultaneously demonstrate a new and original meaning of the political. Certainly, one can assume an interrelation between different local spaces in this process, for example a relation between particular localities as places where one lives, works, thinks and plays. In such localities, the democratic imaginary is re-invented and transformation occurs on multiple levels. And perhaps the most relevant moment to keep in mind here is that, to paraphrase Simon Critchley, true politics in and of itself requires an infinite demand that flows from the perception of injustice [22, p. 121]. In the case of the European Union, this quest for a truly democratic Europe involves therefore, at the same time, the theoretical and practical presuppositions for political, economic and social equality. The premises are interrelated with the process of the creation of an alliance of free and equal states. Finally, it is precisely through the re-creation of both polis and demos that a new Europe of the twenty-first century can be born. 


\title{
References
}

1. Balibar, E. (2016), Europe, Crise et fin?, Paris: Le Bord de l'eau.

2. Beck, U. (2013), German Europe, Cambridge: Polity Press.

3. Habermas, J. (2012), The Crisis of the European Union, Cambridge: Polity Press.

4. Ranciere, J. (2010), Chronicles of Consensual Times, New York: Continuum.

5. Koljević, B. (2015), Twenty-First Century Biopolitics, Frankfurt am Main: Peter Lang International Publishing.

6. Ranciere, J. (2014), Hatred of Democracy, New York: Verso.

7. Cooper, R. (2004), The Breaking of Nations, New York: Grove Press.

8. Fraser, N. and Boltanski, L. (2014), Domination et emancipation pour un renouveau de la critique sociale, Lyon: Presses Universitaries de Lyon.

9. Mouffe, C. (2005), The Democratic Paradox, New York: Verso.

10. Majone, G. (2009), Europe as the Would-Be World Power: The EU at Fifty, Cambridge: Cambridge University Press.

11. Koljević Griffith, B. (2019), Twenty-First Century Europe at the Crossroads, Kritika \& Kontext, vol. 56 , no. 1 , pp. $8-15$.

12. Lefort, C. (1994), L'Invention démocratique, Paris: Fayard.

13. Derrida, J. (2006), Specters of Marx, New York: Routledge.

14. Hobsbawm, E. (2007), Globalisation, Democracy and Terrorism, New York: Little Brown \& Co.

15. Barany, Z. and Moser, R. (eds) (2009), Is Democracy Exportable?, Cambridge: Cambridge University Press.

16. Lazzarato, M. (2014), Signs and Machines, Los Angeles: Semiotext(e).

17. Brown, W. (2015), Undoing the Demos, New York: Zone Books.

18. Urbinati, N. (2006), Representative Democracy, Chicago: University of Chicago Press.

19. Castoriadis, C. (1998), The Imaginary Institution of Society, Cambridge: The MIT Press.

20. Debord, G. (2002), Society of the Spectacle, Detroit: Black \& Red.

21. Hesiod (2015), Theogony, Cambridge: Focus.

22. Critchley, S. (2007), Infinitely Demanding, New York: Verso.

Received: December 18, 2019

Accepted: September 23, 2020

Author's information:

Bogdana N. Koljević Griffith — Dr. Sci. in Philosophy, Research Fellow; bogdana.koljevic@ips.ac.rs

\section{Переосмысление демократии в XXI веке: роль древней демократии}

\author{
Б. Н. Колевич Грифбит \\ Белградский университет, \\ Республика Сербия, 11000, Белград, ул. Светозара Марковича, 36
}

Для цитирования: Koljević Griffith B. N. Rethinking democracy in twenty-first century Europe: The role of ancient democracy // Вестник Санкт-Петербургского университета. Философия и конфликтология. 2020. Т. 36. Вып. 4. С. 700-708. https://doi.org/10.21638/spbu17.2020.408

В статье автор формулирует и обсуждает проблему того, в силу каких причин кризис современного Европейского союза проявляется не просто как кризис так называемого «демократического дефицита» - как наиболее четко сформулировал немецкий философ Юрген Хабермас, - а в гораздо большей степени как структурный и подлинный кризис политической субъективности и демократии как таковой. Это означает, что кризис Европейского союза является системным и относится к концепции политического, особенно в контексте процессов, происходящих в западноевропейской полити- 
ке XXI в. В частности, в этом контексте различение понятий «Европа» и «Европейский союз» раскрывает неолиберальный и постмодернистский характер последнего, что вместе с тем означает борьбу за самоуправление и самостоятельность самой Европы. Более того, автор утверждает, что именно возвращение к концептуализированному опыту классической демократии открывает путь к переосмыслению подлинной демократии современной Европы. Это особенно подчеркивается в отношении как демократических практик, так и самой концепции полиса. В заключение автор утверждает, что новая политика эмансипации, которая семантически восходит прежде всего к значению античных принципов изономии и изегории и, по сути, соотносится с проектом автономии, предлагает эффективную перспективу возрождения принципов классической демократии в современную эпоху. Предложенный в статье проект артикулируется в терминах политики времени (которая связывается с генеалогией политических форм и восходит к греческому концепту kairos) и политики местности (восходящей к концепту demos и описывающей условия и предпосылки становления полиса).

Ключевые слова: Европейский союз, Европа, XXI век, истинная демократия, политическая субъективность, полис.

Статья поступила в редакцию 18 декабря 2019 г.; рекомендована в печать 23 сентября 2020 г.

Контактная информация:

Колевич Гриффит Богдана - д-р философии, науч. сотр.; bogdana.koljevic@ips.ac.rs 